\title{
Basis Pengetahuan untuk Gangguan Perilaku Anak dengan Model Keputusan Kelompok
}

\author{
Ulfatur Rahmah" ${ }^{\# 1}$, Tursina ${ }^{\# 2}$, Helen Sastypratiwi ${ }^{\# 3}$ \\ ${ }^{\#}$ Jurusan Informatika Universitas Tanjungpura \\ JL Prof Dr H Hadari Nawawi, Pontianak, Kalimantan Barat \\ 1 ulfaturahmah@gmail.com \\ 2tursina@informatika.untan.ac.id \\ 3helensastypratiwieinformatics.untan.ac.id
}

\begin{abstract}
Abstrak - Basis pengetahuan merupakan komponen yang penting dalam membangun suatu sistem cerdas terutama yang berkaitan dengan sistem yang membutuhkan kepakaran atau keahlian. Dalam penelitian ini, dibangun sebuah basis pengetahuan dengan model keputusan kelompok, yaitu keputusan yang diambil dari beberapa pakar yang berkaitan dengan gangguan perilaku pada anak. Pakar dalam hal ini berperan sebagai pengambil keputusan dalam memberikan preferensi terhadap gejala yang sudah dikumpulkan. Preferensi yang diberikan oleh pakar yaitu menggunakan format vektor utilitas, format ini memiliki kemiripan dengan konsep fuzzy dimana nilai preferensi yang diberikan yaitu dengan rentang 0 sampai 1. Hasil dari vektor utilitas tersebut kemudian ditransformasikan menjadi relasi preferensi fuzzy dalam bentuk matrik. Matrik preferensi fuzzy yang telah dibentuk diagregasikan dengan operator Ordered Weighted Averaging (OWA) dan dilakukan perangkingan dengan operator Quantifier Guided Dominance Degree (QGDD) untuk mendapatkan nilai bobot rule yang terbentuk atau nilai kinerja. Pada penelitian ini terkumpul sebanyak 20 gejala dengan 5 gangguan perilaku pada anak. Berdasarkan pengujian kevalidan data dengan menggunakan member check dan juga triangulasi . Basis pengetahuan dengan mengimplementasikan model keputusan kelompok ini menghasilkan sebanyak 19 pengetahuan dalam bentuk IF-THEN dengan bobot yang berbeda.
\end{abstract}

Kata kunci - Basis pengetahuan, pakar, model keputusan kelompok, OWA, QGDD

\section{PENDAHULUAN}

Basis pengetahuan mempunyai peranan yang penting dalam keberhasilan suatu sistem yang memerlukan kepakaran karena basis pengetahuan merupakan presentasi pengetahuan dari pakar yang menyimpan aturan-aturan untuk menyelesaikan suatu permasalahan [1]. Basis pengetahuan bertugas menyimpan dan mengelola pengetahuan-pengetahuan yang berisi aturan yang tersusun secara spesifik dan juga berelasi untuk pengambilan suatu keputusan [2]. Basis pengetahuan berisi fakta dan aturan yang digunakan sebagai pemahaman dan penyelesaian dari suatu permasalahan. Dalam penelitian ini dibangun suatu basis pengetahuan yang berkaitan dengan gangguan perilaku pada anak. Gangguan ini ditunjukkan dengan perilaku agresif atau menentang serta tidak dapat mengendalikan diri [3]. Seseorang dapat dikatakan mengalami gangguan perilaku apabila, menyimpang dari perilaku yang oleh orang kebanyakan dianggap normal, penyimpangan yang terjadi cenderung memiliki frekuensi yang tinggi dan penyimpangan tersebut terjadi dalam waktu yang relatif lama [4]. Gangguan perilaku ini cenderung lebih sering terjadi pada anak-anak, karena pada masa anak-anak sedang mengalami proses tumbuh dan kembang. Masalah gangguan perkembangan pada anak ini tidak bisa dianggap sepele, karena gangguan perilaku yang terjadi pada anak dapat menghambat proses pembelajaran anak tersebut yang mengakibatkan akan berpengaruh terhadap perkembangan anak itu sendiri [5] sehingga dibangun basis pengetahuan yang berkaitan dengan gangguan perilaku anak ini sebagai informasi yang didasarkan langsung oleh ahlinya.

Penelitian ini menggunakan model keputusan kelompok dalam membangun basis pengetahuannya. Model keputusan kelompok ini menggunakan lebih dari satu pengambil keputusan atau dalam hal ini disebut pakar untuk mendapatkan pengetahuannya [6]. Keputusan yang didasarkan pada lebih dari satu pakar ini dapat memberikan perbandingan terhadap data yang diperoleh nantinya. Pakar berperan untuk memberikan nilai preferensi atau nilai kepentingan terhadap suatu gejala. Nilai preferensi ini diberikan kepada setiap alternatif atau gejala yang memiliki nilai kepentingan yang berbeda-beda terhadap suatu gangguan [7]. Format preferensi yang digunakan yaitu format utilitas yang memiliki kesamaan dengan fuzzy yang memungkinkan pakar memberikan nilai keputusannya dengan rentang nol hingga satu. Nilai preferensi yang digunakan tersebut akan dilakukan agregasi dan perankingan sehingga menghasilkan suatu 
basis pengetahuan. Basis pengetahuan yang dibangun dengan mengimplementasikan model keputusan kelompok ini nantinya dapat dijadikan sebagai dasar pengetahuan untuk menyelesaikan permasalahan yang berkaitan dengan gangguan perilaku pada anak karena terdapat nilai kinerja atau bobot pada setiap pengetahuannya .

\section{Metodologi PENELITIAN}

Berikut langkah-langkah yang dilakukan untuk membangun basis pengetahuan dapat dilihat pada Gambar 1.

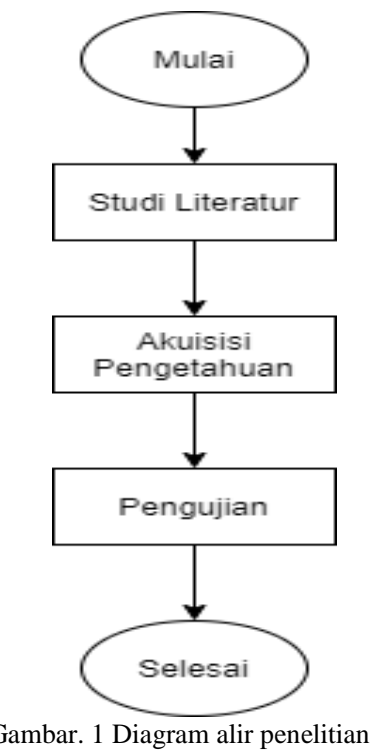

\section{A. Studi Literatur}

Dalam penelitian ini studi literatur yang dilakukan yaitu dengan memperoleh informasi yang berasal dari jurnal, buku dan website terkait dengan penelitian yang diangkat yaitu basis pengetahuan dan gangguan perilaku.

\section{B. Akuisisi Pengetahuan}

Akuisisi pengetahuan merupakan tahapan yang harus dilakukan untuk membangun suatu basis pengetahuan. Akuisisi meliputi proses pengumpulan, pemindahan dan perubahan dari kemampuan pemecahan masalah seorang pakar atau sumber pengetahuan terdokumentasi ke program komputer yang bertujuan untuk memperbaiki atau mengembangkan basis pengetahuan dengan kata lain bahwa akuisisi pengetahuan ini merupakah salah satu tahap yang dilakukan untuk memasukkan pengetahuanpengetahuan yang didapatkan dari pakar [8]. Mengakuisisi pengetahuan selain dari pakar dapat juga dilakukan dari sumber lain seperti orangtua, lingkungan sosial, ataupun guru. Berdasarkan referensi [9], terdapat 5 tahapan dalam akuisisi pengetahuan dapat dilihat pada Gambar 2.

1) Identifikasi: Identifikasi yang dilakukan dalam penelitian ini adalah menentukan sumber pengetahuannya yaitu seorang pakar yaitu seorang psikolog untuk diwawancarai serta mengidentifikasi naskah, jurnal ataupun buku yang terkait untuk mendapatkan data yang digunakan dalam penelitian. Dalam proses memperoleh pengetahuan, data yang akan digunakan yaitu berupa data gejala dan gangguan perilaku pada anak serta dilakukan wawancara terhadap 2 psikolog di Pontianak yaitu psikolog pada rumah Sakit Jiwa Daerah Sei Bangkong yaitu Patricia Elfira Vinny S.Psi, M.Psi dan psikolog pada SLB Bina Anak Bangsa Reni Herawati S.Psi, M.Psi. Hasil pada tahap identifikasi ini yaitu diperoleh 13 gangguan perilaku pada anak.

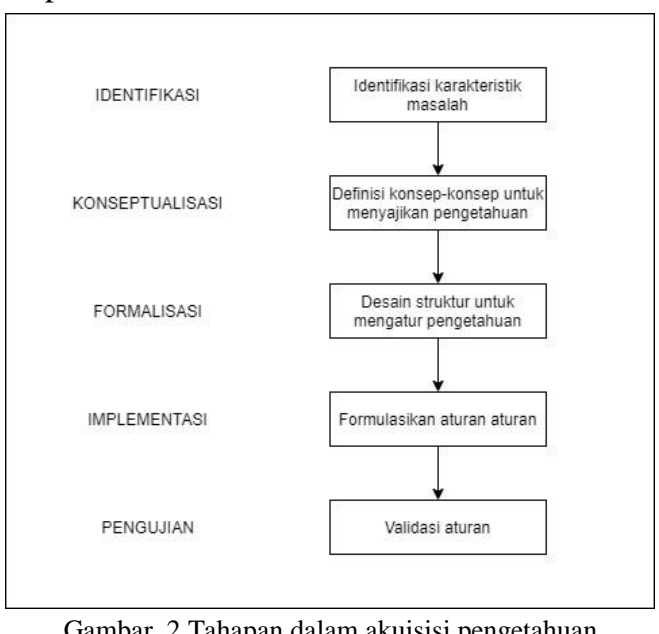

Gambar. 2 Tahapan dalam akuisisi pengetahuan

2) Konseptualisasi: Dilakukan dengan merincikan data-data yang sudah ditentukan bersama pakar sebelumnya, seperti memilih gejala mana saja yang termasuk ke dalam gangguan perilaku pada anak dan gejala yang bukan. Hasil dari tahap konseptualisasi ini yaitu 5 gangguan perilaku pada anak dan 20 gejalanya yang dapat dilihat pada Tabel 1 dan Tabel 2.

3) Formalisasi: Pada tahap ini, dilakukan desain struktur untuk mengatur pengetahuan. Desain struktur ini seperti mengelompokkan gejala-gejala yang sudah didapatkan dengan menentukan gejala apa saja yang mempengaruhi suatu gangguan perilaku kemudian dilanjutkan dengan menentukan proses bagaimana membangun basis pengetahuan.

4) Implementasi: Melakukan perumusan dan perhitungan terhadap data-data gangguan perilaku yang telah didapatkan dari pakar. Dalam tahap implementasi ini didalamnya terdapat beberapa tahapan yang dapat dilakukan untuk mendapatkan basis pengetahuan. Basis pengetahuan yang nantinya akan dibangun yaitu basis pengetahuan yang berbasis aturan. Setiap aturan memiliki anteseden yang sama sesuai dengan keterkaitan antar fitur yang diberikan dan setiap fitur berelasi dengan menggunakan operator AND [10]. Representasi pakar dalam hal ini yaitu menentukan nilai preferensi. Seorang pakar akan memberikan inisiasi terhadap gejala-gejala yang mungkin muncul. Basis pengetahuan yang akan dibangun berdasarkan hasil dari nilai preferensi yang didapatkan dari pakar, kemudian dilanjutkan dengan mengubah nilai preferensi pakar menjadi matriks relasi preferensi fuzzy. Setelah itu dilakukan agregasi dengan operator OWA yang kemudian 
akan dilakukan proses kuantifikasi dengan QGDD. Proses dari pembangunan basis pengetahuan ini dapat dilihat pada Gambar 3.

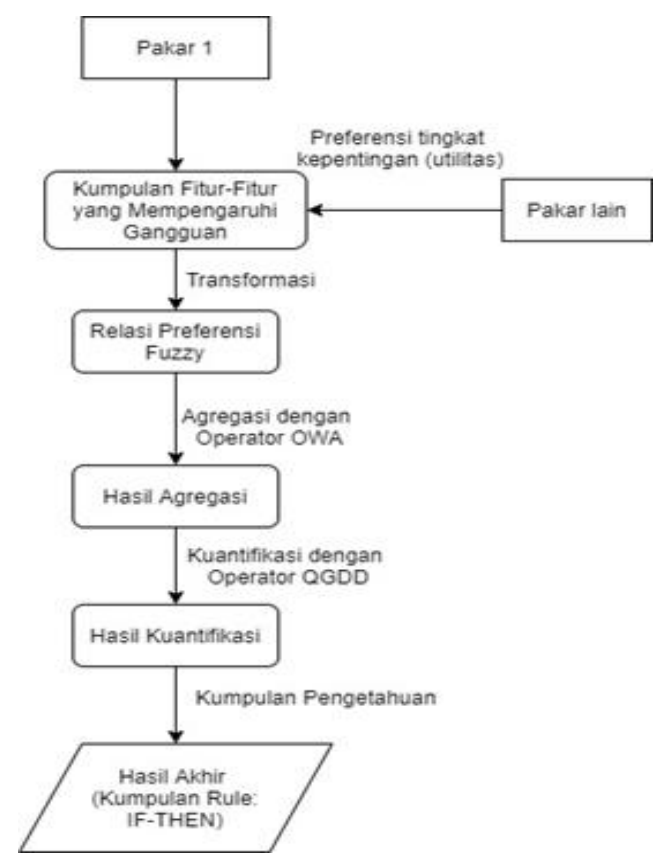

Gambar. 3. Proses pembangunan basis pengetahuan

\section{Format Preferensi}

Dalam model keputusan kelompok ini, pengambil keputusan akan memberikan nilai preferensi yang akan digunakan untuk memberikan nilai kepentingan suatu alternatif diantara alternatif lainnya. Ada beberapa format preferensi yang dapat digunakan untuk memberikan nilai prefrensi, namun dalam penelitian ini format preferensi yang digunakan yaitu dalam format vektor utilitas (utility vectors). Preferensi pengambil keputusan akan diberikan dalam format yang sama dengan fuzzy yaitu nilai yang memiliki derajat keanggotaaan 0 sampai dengan 1 [11]. Nilai preferensi ini diberikan berdasarkan kepentingan dari setiap gejala terhadap gangguan yang diberikan.

\section{Relasi Prefrerensi Fuzzy}

Relasi preferensi adalah penyajian informasi yang digunakan dalam permasalahan pengambilan keputusan terutama ketika akan mengumpulkan pilihan seorang pakar ke dalam pilihan kelompok [12]. Relasi preferensi ini dibuat dalam bentuk matrik dengan mentransformasikan nilai preferensi dari pakar. Untuk mengubah nilai preferensi pakar menjadi matriks relasi preferensi fuzzy maka digunakan rumus persamaan (1).

$$
p_{i j}^{k}=\frac{\left(u_{i}^{k}\right)^{2}}{\left(u_{i}^{k}\right)^{2}+\left(u_{j}^{k}\right)^{2}} ; \quad 1 \leq i \neq j \leq m
$$

dengan :

$$
\begin{array}{ll}
\mathrm{P}_{\mathrm{ij}} & =\text { Matriks } \mathrm{P} \\
\mathrm{u}_{\mathrm{i}} & =\text { Nilai baris } \\
\mathrm{u}_{\mathrm{j}} & =\text { Nilai Kolom }
\end{array}
$$

\section{E. $O W A$}

Operator OWA adalah metode efektif yang digunakan untuk melakukan agregasi terhadap relasi preferensi fuzzy. Operator agregasi ini digunakan dengan mempertimbangkan nilai preferensi yang diberikan oleh pengambil keputusan. Cara kerja operator OWA yaitu mengagregasikan nilai tanggapan yang diberikan oleh pengambil keputusan yang sebelumnya telah diurutkan berdasarkan besarnya nilai tanggapan yang diberikan tersebut [13]. Cara untuk menghitung bobot dari operator OWA ini dengan menggunakan pengukur fuzzy Q. yang merupakan suatu pengukur proportional non decreasing yang dirumuskan pada persamaan (2).

$$
\mathrm{Q}(\mathrm{r})=\mathrm{r}^{1 / 2}
$$

Sehingga untuk Q kriteria atau pakar dapat dihitung bobot-bobot OWA. Bobot ini nantinya akan digunakan untuk menghitung matriks $\mathrm{P}^{\mathrm{c}}$ sebagai matriks agregasi dengan formula yang ditunjukkan pada persamaan persamaan (3) .

$$
w_{i}=Q\left(\frac{i}{n}\right)-Q\left(\frac{i-1}{n}\right) ; \quad i=1, \ldots, n .
$$

dengan :

$\mathrm{i} \quad=$ nilai $\mathrm{ke}-\mathrm{i}$

$\mathrm{n} \quad=$ jumlah pengambil keputusan

\section{F. $Q G D D$}

QGDD atau Quantifier Guided Dominance Degree digunakan untuk memilih alternatif dengan mempertimbangkan matriks agregasi yang telah diperoleh dari pengambil keputusan. Operator ini akan mengkuantifikasi dominasi suatu alternatif terhadap alternatif yang lainnya [14]. Formula yang digunakan dalam operator QGDD ini adalah pada persamaan (4).

$$
\mathrm{QGDD}(\mathrm{Pc} j \mathrm{n}) \mathrm{i} \mathrm{Q} i \mathrm{j}=\varphi_{s}=1
$$

\section{HASIL DAN PEMBAHASAN}

Dalam penelitian ini data yang dikumpulkan berupa data gejala dan gangguan yang didapatkan dari hasil studi literatur dan wawancara kepada beberapa pakar dalam hal ini adalah psikolog yang bersinggungan langsung kepada anak yang memiliki gangguan perilaku. Berdasarkan hasil studi literatur dan wawancara terhadap pakar telah terkumpul sebanyak 20 gejala dengan 5 gangguan perilaku pada anak. Data gejala dan gangguan yang terkumpul tersebut dapat dibuat menjadi sebuah tabel keputusan dimana terdapat hubungan antara gejala dan gangguan [15]. Tabel daftar gejala dan gangguan dapat dilihat pada Tabel 1 dan Tabel 2 . 
TABEL I

DAFTAR GEJALA

\begin{tabular}{|l|l|l|}
\hline $\begin{array}{l}\text { Gejala } \\
\text { ke- }\end{array}$ & Kode & Gejala \\
\hline 1 & S001 & Mudah Marah \\
\hline 2 & S002 & Suka menggunakan kekerasan fisik \\
\hline 3 & S003 & Perilaku yang tidak terkontrol \\
\hline 4 & S004 & Agresif, bahkan melukai diri sendiri \\
\hline 5 & S005 & $\begin{array}{l}\text { Sulit memusatkan perhatian atau } \\
\text { berkonsentrasi }\end{array}$ \\
\hline 6 & S006 & Tidak berhenti bicara \\
\hline 7 & S007 & $\begin{array}{l}\text { Sulit untuk duduk diam dalam waktu } \\
\text { yang lama }\end{array}$ \\
\hline 8 & S008 & Sering melanggar peraturan \\
\hline 9 & S009 & $\begin{array}{l}\text { Sering menyalahkan orang lain atas } \\
\text { kesalahannya sendiri }\end{array}$ \\
\hline 10 & S010 & $\begin{array}{l}\text { Sering berdebat dengan orang yang } \\
\text { lebih tua }\end{array}$ \\
\hline 11 & S011 & $\begin{array}{l}\text { Mudah kehilangan kesabaran atau } \\
\text { bertindak tidak sabaran }\end{array}$ \\
\hline 12 & S012 & $\begin{array}{l}\text { Memiliki perilaku yang kejam } \\
\text { terhadap orang lain bahkan terhadap } \\
\text { hewan }\end{array}$ \\
\hline 13 & S013 & Sering berbohong \\
\hline 14 & S014 & Sering mengintimidasi orang lain \\
\hline 15 & S015 & $\begin{array}{l}\text { Tidak memiliki rasa empati terhadap } \\
\text { orang lain }\end{array}$ \\
\hline 16 & S016 & Sering melakukan serangan verbal \\
\hline 17 & S017 & $\begin{array}{l}\text { Menginginkan sesuatu dengan cara } \\
\text { mengamuk }\end{array}$ \\
\hline 18 & S018 & $\begin{array}{l}\text { Tidak dapat mengungkapkan kepada } \\
\text { diang dewasa mengenai hal yang }\end{array}$ \\
\hline 20 & $\begin{array}{l}\text { Suka merebut sesuatu secara paksa } \\
\text { dari orang lain }\end{array}$ \\
\hline Cenderung memaksakan kehendak \\
\hline 19
\end{tabular}

TABEL II

DAFTAR GANGGUAN

\begin{tabular}{|l|l|l|}
\hline No & Kode & Nama Gangguan \\
\hline 1 & P001 & Temper Tantrum \\
\hline 2 & P002 & ADHD (Hiperaktif) \\
\hline 3 & P003 & ODD \\
\hline 4 & P004 & Conduct Disorder \\
\hline 5 & P005 & Agresivitas \\
\hline
\end{tabular}

Langkah awal dalam membangun basis pengetahuan adalah mendapatkan nilai preferensi. Nilai preferensi ini diberikan oleh pakar kepada masing-masing gejala terhadap gangguan yang terjadi. Setiap pakar atau pengambil keputusan akan memberikan nilai preferensi dalam format vektor utilitas untuk menanggapi kemungkinan yang muncul pada satu gejala diantara gejala yang lainnya. Nilai preferensi tersebut disajikan pada Tabel 3 untuk gangguan temper tantrum.

TABEL III

DAFTAR NILAI PREFERENSI DARI KEDUA PAKAR

\begin{tabular}{|c|c|l|c|c|}
\hline No & $\begin{array}{c}\text { Kode } \\
\text { Gejala }\end{array}$ & Nama Gejala & $\begin{array}{c}\text { Nilai } \\
\text { Preferensi } \\
\text { Pakar 1 }\end{array}$ & $\begin{array}{c}\text { Nilai } \\
\text { Preferensi } \\
\text { Pakar 2 }\end{array}$ \\
\hline 1 & S001 & Mudah Marah & 1 & 1 \\
\hline 2 & S002 & $\begin{array}{l}\text { Suka menggunakan } \\
\text { kekerasan fisik }\end{array}$ & 0,4 & 0,5 \\
\hline 3 & S003 & $\begin{array}{l}\text { Perilaku yang tidak } \\
\text { terkontrol }\end{array}$ & 1 & 1 \\
\hline 4 & S004 & $\begin{array}{l}\text { Agresif, bahkan } \\
\text { melukai diri sendiri }\end{array}$ & 0,4 & 0,5 \\
\hline 5 & S017 & $\begin{array}{l}\text { Menginginkan } \\
\text { sesuatu dengan } \\
\text { cara mengamuk }\end{array}$ & 1 & 1 \\
\hline S018 & $\begin{array}{l}\text { Tidak dapat } \\
\text { mengungkapkan } \\
\text { kepada orang } \\
\text { dewasa mengenai } \\
\text { hal yang diinginkan }\end{array}$ & 0,2 & 0,5 \\
\hline
\end{tabular}

Selanjutnya nilai preferensi tersebut ditransformasikan ke bentuk relasi preferensi fuzzy dengan menggunakan persamaan 1, maka diperoleh matriks relasi preferensi fuzzy seperti berikut:

$\mathrm{P} 1=\left[\begin{array}{llllll}0,50 & 0,86 & 0,50 & 0,86 & 0,50 & 0,96 \\ 0,13 & 0,50 & 0,13 & 0,50 & 0,13 & 0,80 \\ 0,50 & 0,86 & 0,50 & 0,86 & 0,50 & 0,96 \\ 0,13 & 0,50 & 0,13 & 0,50 & 0,13 & 0,80 \\ 0,50 & 0,86 & 0,50 & 0,86 & 0,50 & 0,96 \\ 0,03 & 0,20 & 0,03 & 0,20 & 0,03 & 0,50\end{array}\right]$

$\mathrm{P} 2=\left[\begin{array}{llllll}0,50 & 0,80 & 0,50 & 0,80 & 0,50 & 0,80 \\ 0,20 & 0,50 & 0,20 & 0,50 & 0,20 & 0,50 \\ 0,50 & 0,80 & 0,50 & 0,80 & 0,50 & 0,80 \\ 0,20 & 0,50 & 0,20 & 0,50 & 0,20 & 0,50 \\ 0,50 & 0,80 & 0,50 & 0,80 & 0,50 & 0,80 \\ 0,20 & 0,50 & 0,20 & 0,50 & 0,20 & 0,50\end{array}\right]$

Proses agregasi dilakukan untuk membentuk matriks agregasi, berdasarkan persamaan 2 dan 3 maka didapatkan bobot OWA nya adalah

$$
\begin{aligned}
& \mathrm{W} 1=\mathrm{Q}\left(\frac{1}{2}\right)-\mathrm{Q}\left(\frac{0}{2}\right)=\sqrt{\frac{1}{2}}-\sqrt{0}=0,70 \\
& \mathrm{~W} 2=\mathrm{Q}\left(\frac{2}{2}\right)-\mathrm{Q}\left(\frac{1}{2}\right)=\sqrt{\frac{2}{2}}-\sqrt{\frac{1}{2}}=\sqrt{1}-\sqrt{\frac{1}{2}}=0,29
\end{aligned}
$$


Dengan matriks agregasi OWA nya:

$\mathrm{P}^{\mathrm{C}}=\left[\begin{array}{llllll}0,49 & 0,83 & 0,49 & 0,83 & 0,49 & 0,90 \\ 0,15 & 0,49 & 0,15 & 0,495 & 0,15 & 0,70 \\ 0,49 & 0,83 & 0,49 & 0,834 & 0,49 & 0,90 \\ 0,15 & 0,49 & 0,14 & 0,495 & 0,15 & 0,70 \\ 0,49 & 0,83 & 0,49 & 0,834 & 0,49 & 0,90 \\ 0,08 & 0,28 & 0,08 & 0,285 & 0,08 & 0,49\end{array}\right]$

Nilai matriks tersebut belum konsisten, sehingga harus ditransformasikan terlebih dahulu. Suatu matriks dapat dikatakan konsisten apabila $x i j+x j i=1$, sehingga diperoleh:

$\mathrm{P}^{\mathrm{C}},=\left[\begin{array}{llllll}0,50 & 0,85 & 0,50 & 0,85 & 0,50 & 0,92 \\ 0,15 & 0,50 & 0,15 & 0,50 & 0,15 & 0,71 \\ 0,50 & 0,85 & 0,50 & 0,85 & 0,50 & 0,92 \\ 0,15 & 0,50 & 0,15 & 0,50 & 0,15 & 0,71 \\ 0,50 & 0,85 & 0,50 & 0,85 & 0,50 & 0,92 \\ 0,08 & 0,29 & 0,08 & 0,29 & 0,08 & 0,50\end{array}\right]$

Setelah didapatkan matriks konsisten maka selanjutnya dilakukan kuatifikasi dengan QGDD. Terdapat 6 gejala yang mempengaruhi gangguan pertama sehingga,

$$
\begin{aligned}
& \mathrm{W} 1=\mathrm{Q}\left(\frac{1}{6}\right)=\sqrt{\frac{1}{6}}=0,41 \\
& \mathrm{~W} 2=\mathrm{Q}\left(\frac{2}{6}\right)-\mathrm{Q}\left(\frac{1}{6}\right)=\sqrt{\frac{2}{6}}-\sqrt{\frac{1}{6}}=0,17 \\
& \mathrm{~W} 3=\mathrm{Q}\left(\frac{3}{6}\right)-\mathrm{Q}\left(\frac{2}{6}\right)=\sqrt{\frac{3}{6}}-\sqrt{\frac{2}{6}}=0,13 \\
& \mathrm{~W} 4=\mathrm{Q}\left(\frac{4}{6}\right)-\mathrm{Q}\left(\frac{3}{6}\right)=\sqrt{\frac{4}{6}}-\sqrt{\frac{3}{6}}=0,11 \\
& \mathrm{~W} 5=\mathrm{Q}\left(\frac{5}{6}\right)-\mathrm{Q}\left(\frac{4}{6}\right)=\sqrt{\frac{5}{6}}-\sqrt{\frac{4}{6}}=0,10 \\
& \mathrm{~W} 6=\mathrm{Q}\left(\frac{6}{6}\right)-\mathrm{Q}\left(\frac{5}{6}\right)=\sqrt{\frac{6}{6}}-\sqrt{\frac{5}{6}}=\sqrt{1}-\sqrt{\frac{1}{2}}=0,09
\end{aligned}
$$

Dengan persamaan 5 maka didapatkan nilai bobot akhirnya adalah sebagai berikut. $\mathrm{C}_{1}=\{0.7822,0.4861$, $0.7822,0.4861,0.7822,0.3160\}$. Nilai bobot bobot ini akan menjadi bobot basis pengetahuannya dan selanjutnya dapat dijadikan sebagai bobot untuk proses inferensi. Jumlah rule atau aturan yang akan dihasilkan pada basis pengetahuan sama dengan jumlah gejala yang menjadi alternatif. Misalnya pada gangguan pertama terdapat 6 gejala maka pada gangguan pertama ini akan menghasilkan 6 pengetahuan dengan gejala yang sama namun memiliki bobot yang berbeda, dalam beberapa kondisi terdapat nilai bobot yang sama dikarenakan nilai

\begin{tabular}{|c|c|c|}
\hline No & Rule & Bobot \\
\hline 1 & IF S005 AND S006 AND S007 AND S008 AND S011 THEN P002 & 0,3178 \\
\hline 2 & IF S005 AND S006 AND S007 AND S008 AND S011 THEN P002 & 0,5666 \\
\hline 3 & IF S005 AND S006 AND S007 AND S008 AND S011 THEN P002 & 0,5502 \\
\hline 4 & IF S001 AND S008 AND S009 AND S010 AND S011 THEN P003 & 0,641 \\
\hline 5 & IF S001 AND S008 AND S009 AND S010 AND S011 THEN P003 & 0,6946 \\
\hline 6 & IF S001 AND S008 AND S009 AND S010 AND S011 THEN P003 & 0,3754 \\
\hline 7 & IF S001 AND S008 AND S009 AND S010 AND S011 THEN P003 & 0,4124 \\
\hline 8 & $\begin{array}{l}\text { IF S001 AND S008 AND S009 AND S012 AND S013 AND S014 } \\
\text { AND S015 THEN P004 }\end{array}$ & 0,5706 \\
\hline 9 & $\begin{array}{l}\text { IF S001 AND S008 AND S009 AND S012 AND S013 AND S014 } \\
\text { AND S015 THEN P004 }\end{array}$ & 0,4991 \\
\hline 10 & $\begin{array}{l}\text { IF S001 AND S008 AND S009 AND S012 AND S013 AND S014 } \\
\text { AND S015 THEN P004 }\end{array}$ & 0,3641 \\
\hline 11 & $\begin{array}{l}\text { IF S001 AND S008 AND S009 AND S012 AND S013 AND S014 } \\
\text { AND S015 THEN P004 }\end{array}$ & 0,696 \\
\hline 12 & $\begin{array}{l}\text { IF S001 AND S008 AND S009 AND S012 AND S013 AND S014 } \\
\text { AND S015 THEN P004 }\end{array}$ & 0,6741 \\
\hline 13 & IF S001 AND S002 AND S016 AND S019 AND S020 THEN P005 & 0.6830 \\
\hline 14 & IF S001 AND S002 AND S016 AND S019 AND S020 THEN P005 & 0.4012 \\
\hline 15 & IF S001 AND S002 AND S016 AND S019 AND S020 THEN P005 & 0.3640 \\
\hline 16 & $\begin{array}{l}\text { IF S001 AND S008 AND S009 AND S012 AND S013 AND S014 } \\
\text { AND S015 THEN P004 }\end{array}$ & 0,6741 \\
\hline 17 & IF S001 AND S002 AND S016 AND S019 AND S020 THEN P005 & 0.6830 \\
\hline 18 & IF S001 AND S002 AND S016 AND S019 AND S020 THEN P005 & 0.4012 \\
\hline 19 & IF S001 AND S002 AND S016 AND S019 AND S020 THEN P005 & 0.3640 \\
\hline
\end{tabular}
preferensi yang diberikan oleh kedua pakar sama, maka dilakukan eliminasi terhadap bobot yang sama. Sehingga diperoleh rule seperti pada Tabel 4.

\section{TABEL IV}

Basis PENGetahuan yang TeRbentuk

Berdasarkan hasil perhitungan yang telah dilakukan sebelumnya maka terbentuk sebanyak 19 pengetahuan dalam bentuk IF-THEN. Pengetahuan yang berbentuk rule inilah yang kemudian disebut sebagai basis pengetahuan. Basis pengetahuan yang terbentuk telah memiliki sejumlah aturan yang tersusun secara spesifik dan juga berelasi dimana basis pengetahuan ini dapat dijadikan sebagai dasar dari pemikiran yang dapat digunakan pada 
sistem pakar, terutama pada sistem yang berbasis pengetahuan.

\section{A. Pengujian}

Pengujian dilakukan dengan mencocokkan antara basis pengetahuan yang dihasilkan dengan kasus yang sebenarnya atau sebelumnya terjadi, pengujian ini dinamakan dengan uji kasus. Uji kasus dilakukan untuk memahami individu secara lebih mendalam, hal ini dilakukan untuk mengumpulkan dan mendapatkan pemahaman mengenai individu yang diteliti dan permasalahan yang dihadapi supaya dapat terselesaikan [16]. Uji kasus ini dilakukan dengan memberikan kuesioner kepada guru serta orang tua di lingkungan anak yang memiliki gangguan perilaku. Orang tua atau guru akan mengisi lembar yang berisi gejala yang disertai dengan gangguan, gejala dan gangguan tersebut akan diisi sesuai dengan kondisi anak yang sebenarnya. Bentuk dari kuesioner tersebut dapat dilihat pada Tabel 5 berikut.

TABEL V

FORM KUESIONER

\section{Jenis Kelamin : Perempuan / Laki-laki}

Umur

Petunjuk pengisian : Centang $(\sqrt{ })$ pada setiap gejala yang dirasakan pada anak berdasarkan hasil pengamatan langsung pada anak

\begin{tabular}{|c|c|}
\hline No & Nama Gejala \\
\hline 1 & Mudah Marah \\
\hline 2 & Suka menggunakan kekerasan fisik \\
\hline 3 & Perilaku yang tidak terkontrol \\
\hline 4 & agresif, bahkan melukai diri sendiri \\
\hline 5 & Sulit memusatkan perhatian atau berkonsentrasi \\
\hline 6 & Tidak berhenti bicara \\
\hline 7 & Sulit untuk duduk diam dalam waktu yang lama \\
\hline 8 & Sering melanggar peraturan \\
\hline 9 & $\begin{array}{l}\text { Sering menyalahkan orang lain atas } \\
\text { kesalahannya sendiri }\end{array}$ \\
\hline 10 & Sering berdebat dengan orang yang lebih tua \\
\hline 11 & $\begin{array}{l}\text { Mudah kehilangan kesabaran atau bertindak } \\
\text { tidak sabaran }\end{array}$ \\
\hline 12 & $\begin{array}{l}\text { Memiliki perilaku yang kejam terhadap orang } \\
\text { lain bahkan terhadap hewan }\end{array}$ \\
\hline 13 & Sering berbohong \\
\hline 14 & Sering mengintimidasi orang lain \\
\hline 15 & Tidak memiliki rasa empati terhadap orang lain \\
\hline
\end{tabular}

\begin{tabular}{|c|c|}
\hline No & Nama Gejala \\
\hline 16 & Sering melakukan serangan verbal \\
\hline 17 & Menginginkan sesuatu dengan cara mengamuk \\
\hline 19 & $\begin{array}{l}\text { Suka merebut sesuatu secara paksa dari orang } \\
\text { lain }\end{array}$ \\
\hline 20 & Cenderung memaksakan kehendak \\
\hline \multicolumn{2}{|c|}{$\begin{array}{l}\text { Kecenderungan menderita gangguan perilaku pada } \\
\text { anak: }\end{array}$} \\
\hline 1 & Temper Tantrum \\
\hline 2 & ADHD / Hiperaktif \\
\hline 3 & ODD \\
\hline 4 & Conduct Disorder \\
\hline 5 & Agresivitas \\
\hline
\end{tabular}

Kuesioner ini akan dilakukan pengujian kepada 10 orang anak secara acak. Hasil dari kuesioner ini nantinya akan dbandingkan dengan basis pengetahuan yang sudah terbentuk sebelumnya. Hasil dari kuesioner dapat dilihat pada Tabel VI.

Basis pengetahuan yang dibangun sebelumnya akan dibandingkan dengan hasil kuesioner pada 10 orang anak ini. Sebagai contoh dapat dilihat bahwa pada kasus pertama yaitu seorang anak laki-laki yang mempunyai gejala S001-S002-S003-S004-S011-S017-S018 menunjukkan bahwa anak tersebut memiliki kecenderungan gangguan perilaku temper tantrum. Informasi ini sesuai dengan basis pengetahuan yang dibangun dimana pada basis pengetahuan untuk gangguan temper tantrum memiliki gejala diantaranya S001-S002S003-S004-S017-S018. Terdapat 1 gejala yaitu S011 tidak termasuk pada basis pengetahuan untuk gangguan temper tantrum. Perbedaan 1 gejala ini tidak begitu berpengaruh terhadap kebenaran basis pengetahuan karena pada masing-masing anak gejala yang muncul tidak selalu sama dan seorang anak dapat dikatakan memiliki gangguan perilaku apabila mengalami setidaknya 3 gejala dalam waktu yang relatif lama dan berulang. Jika hasil pada kuesioner memiliki informasi yang sama dengan hasil pada basis pengetahuan, maka basis pengetahuan yang dibangun sudah dapat dikatakan memiliki informasi yang benar, selain itu data pada basis pengetahuan yang dibangun akan diuji kredibilitasnya berdasarkan Triangulasi dan Member check.

\section{B. Triangulasi}

Pengecekan data dari berbagai aspek yaitu sumber, teknik dan waktu.

- Triangulasi sumber : Pada penelitian ini sumber data yang diperoleh berasal dari wawancara dan jurnal atau buku. Data yang diperoleh dari wawancara kepada pakar dan dari buku/jurnal memiliki data yang sama walaupun dari sumber 
yang berbeda yaitu ditemukannya kesamaan jenis gangguan perilaku pada anak dan gejalanya.

- Triangulasi Teknik : Pada penelitian ini dilakukan wawancara kepada 2 pakar dan untuk pengcekan datanya dilakukan dengan kuesioner dan observasi

- Triangulasi Waktu : Data yang diperoleh oleh peneliti dengan wawancara bersama pakar memiliki nilai yang sama walaupun dilakasanakan pada waktu yang berbeda.

\section{Member Check}

Member Check Merupakan proses pengecekan data yang dilakukan kepada pakar sebagai pemberi data untuk diketahui apakah hasil dari penelitian sudah disepakati [17]. Hasil kuesioner pada Tabel VI akan diberikan kepada kedua pakar untuk disepakati apakah sudah memiliki informasi yang tepat. Hasil dari pengecekan terhadap kedua pakar, keduanya sudah menyepakati bahwa data hasil kuesioner memang benar yang terjadi pada anak dengan gejala dan gangguan yang dialaminya dan sesuai dengan basis pengetahuan yang dibangun dan diakui kebenarannya.

Berdasarkan hasil uji kasus yang telah dilakukan terhadap 10 orang anak, dapat diketahui bahwa terdapat kecocokan antara basis pengetahuan yang dibangun dengan kondisi anak yang sebenarnya terjadi. Kebenaran basis pengetahuan ini diuji telah diuji melalui proses triangulasi dan member check kepada pakar sehingga basis pengetahuan yang dibangun memiliki informasi atau data yang valid.

TABEL VI

PENGUJIAN TERHADAP 10 ORANG ANAK

\begin{tabular}{|c|c|c|c|c|c|c|c|c|c|c|c|c|c|c|c|c|c|c|c|c|c|c|c|}
\hline \multirow[b]{2}{*}{ No } & \multirow[b]{2}{*}{ Umur } & \multirow[b]{2}{*}{$\begin{array}{c}\text { Jenis } \\
\text { Kelamin }\end{array}$} & \multicolumn{20}{|c|}{ GEJALA } & \multirow[b]{2}{*}{ Gangguan } \\
\hline & & & $\begin{array}{l}\text { S } \\
\mathbf{0} \\
\mathbf{0} \\
\mathbf{1}\end{array}$ & $\begin{array}{l}S \\
0 \\
0 \\
2\end{array}$ & $\begin{array}{l}\mathbf{S} \\
\mathbf{0} \\
\mathbf{0} \\
\mathbf{3} \\
\end{array}$ & $\begin{array}{l}S \\
0 \\
0 \\
4\end{array}$ & \begin{tabular}{l|}
$\mathbf{S}$ \\
$\mathbf{0}$ \\
$\mathbf{0}$ \\
$\mathbf{5}$
\end{tabular} & $\begin{array}{l} \\
0 \\
0 \\
6\end{array}$ & $\begin{array}{l}S \\
0 \\
0 \\
7\end{array}$ & $\begin{array}{l}\text { S } \\
\text { 0 } \\
0 \\
8\end{array}$ & $\begin{array}{l}\mathbf{S} \\
\mathbf{0} \\
\mathbf{0} \\
\mathbf{9}\end{array}$ & $\begin{array}{l}\mathbf{S} \\
\mathbf{0} \\
\mathbf{1} \\
\mathbf{0}\end{array}$ & $\begin{array}{l}\mathbf{S} \\
\mathbf{0} \\
\mathbf{1} \\
\mathbf{1}\end{array}$ & $\begin{array}{l}S \\
0 \\
1 \\
2 \\
\end{array}$ & $\begin{array}{l}\mathbf{S} \\
\mathbf{0} \\
\mathbf{1} \\
\mathbf{3} \\
\end{array}$ & $\begin{array}{l} \\
0 \\
1 \\
4\end{array}$ & $\begin{array}{l}\text { S } \\
\mathbf{0} \\
\mathbf{1} \\
\mathbf{5}\end{array}$ & $\begin{array}{l}S \\
0 \\
1 \\
6\end{array}$ & $\begin{array}{l}S \\
0 \\
1 \\
7\end{array}$ & \begin{tabular}{|l}
$S$ \\
0 \\
1 \\
8
\end{tabular} & $\begin{array}{l}\mathbf{S} \\
\mathbf{0} \\
\mathbf{1} \\
\mathbf{9}\end{array}$ & $\begin{array}{l}\mathbf{S} \\
\mathbf{0} \\
\mathbf{2} \\
\mathbf{0} \\
\end{array}$ & \\
\hline 1 & 11 tahun & Laki-laki & $\sqrt{ }$ & $\sqrt{ }$ & $\sqrt{ }$ & $\sqrt{ }$ & & & & & & & $\sqrt{ }$ & & & & & & $\sqrt{ }$ & $\sqrt{ }$ & & & Temper Tantrum \\
\hline 2 & 9 tahun & Laki-laki & $\sqrt{ }$ & $\sqrt{ }$ & & & & & & & $\sqrt{ }$ & & $\sqrt{ }$ & & & & & $\sqrt{ }$ & & & $\sqrt{ }$ & $\sqrt{ }$ & Agresivitas \\
\hline 3 & 10 tahun & Perempuan & $\sqrt{ }$ & & $\sqrt{ }$ & $\sqrt{ }$ & & & & & & & $\sqrt{ }$ & & & & & & $\sqrt{ }$ & $\sqrt{ }$ & $\sqrt{ }$ & $\sqrt{ }$ & Temper Tantrum \\
\hline 4 & 8 tahun & Perempuan & $\sqrt{ }$ & & $\sqrt{ }$ & $\sqrt{ }$ & $\sqrt{ }$ & & & & & & & & & & & & $\sqrt{ }$ & $\sqrt{ }$ & & $\sqrt{ }$ & Temper Tantrum \\
\hline 5 & 12 tahun & Laki-laki & $\sqrt{ }$ & $\sqrt{ }$ & & & & & & & & & & & & & & $\sqrt{ }$ & & & $\sqrt{ }$ & $\sqrt{ }$ & Agresivitas \\
\hline 6 & 10 tahun & Laki-laki & & & $\sqrt{ }$ & & $\sqrt{ }$ & $\sqrt{ }$ & $\sqrt{ }$ & $\sqrt{ }$ & & & $\sqrt{ }$ & & & & & & & & & & ADHD \\
\hline 7 & 8 tahun & Laki-laki & $\sqrt{ }$ & $\sqrt{ }$ & $\sqrt{ }$ & $\sqrt{ }$ & & & & & & & & & & & & & $\sqrt{ }$ & $\sqrt{ }$ & & & Temper Tantrum \\
\hline 8 & 6 tahun & Perempuan & $\sqrt{ }$ & & & & & & & $\sqrt{ }$ & $\sqrt{ }$ & $\sqrt{ }$ & $\sqrt{ }$ & & & & & & & & & $\sqrt{ }$ & ODD \\
\hline 9 & 5 tahun & Laki-laki & & & $\sqrt{ }$ & & $\sqrt{ }$ & & $\sqrt{ }$ & $\sqrt{ }$ & $\sqrt{ }$ & & $\sqrt{ }$ & & & & & & $\sqrt{ }$ & & & & ADHD \\
\hline 10 & 3 tahun & Perempuan & & & $\sqrt{ }$ & & $\sqrt{ }$ & & $\sqrt{ }$ & & & & $\sqrt{ }$ & & & & & & & & & & ADHD \\
\hline
\end{tabular}

\section{KESIMPULAN}

Berdasarkan hasil analisis yang telah dilakukan sebelumnya, dapat disimpulkan bahwa model keputusan kelompok ini dapat digunakan untuk membangun suatu basis pengetahuan berdasarkan nilai preferensi dari dua orang pakar. Selain itu dapat diketahui bahwa dari 20 gejala dan 5 gangguan yang terkumpul dapat dibentuk sebanyak 19 pengetahuan dengan disertai bobotnya. Pengujian yang dilakukan kepada 10 orang anak yang memiliki kecenderungan gangguan perilaku, menunjukkan adanya kecocokan antara gejala yang terjadi pada anak tersebut dan gejala yang dihasilkan pada basis pengetahuan dengan menggunakan uji kasus, triangulasi dan member check. Berdasarkan hasil dari kuesioner yang telah dikumpulkan dapat disimpulkan juga bahwa gangguan perilaku pada anak lebih cenderung terjadi pada anak laki-laki dibandingkan anak perempuan, informasi ini sesuai dengan apa yang didapatkan peneliti saat melakukan wawancara pada pakar yang menyatakan bahwa anak laki-laki lebih banyak mengalami gangguan perilaku dibandingkan anak perempuan. Selain itu dalam penelitian ini juga didapatkan nilai kinerja yaitu berupa bobot-bobot yang dihasilkan pada rule. Bobot ini nantinya dapat digunakan untuk proses inferensi pada sistem berbasis kepakaran atau sistem pakar untuk menentukan gangguan perilaku yang terjadi pada anak.

\section{DAFTAR PUSTAKA}

[1] G. A. D. Sugiharni and D. G. H. Divayana, "Pemanfaatan Metode Forward Chaining Dalam," Jurnal Nasional Pendidikan Teknik Informatika (JANAPATI), vol. 6, no. 1, pp. 20-29, 2017.

[2] M. M. Gibran, H. Mubarok and Rianto, "Implementas Knowledge Base pada Aplikasi Data Orang Hilang (Studi Kasus : Polres Tasikmalaya Kota)," Jurnal Edukasi dan Penelitian Informatika (JEPIN) , vol. 3, no. 2, pp. 96-103, 2017.

[3] Khairina and J. Efendi, "Efektivitas Role Playing Untuk Menguangi Perilaku Agresif Anak dengan Gangguan Perilaku," Jurnal Penelitian Pendidikan Kebutuhan Khusus, vol. 6, no. 1, pp. 126-133, 2018. 
[4] G. Nelson, "Moderators of Women's and Children Adjusment Following Parental Divorce," Journal of Divorce, vol. 3, p. 4, 1981.

[5] R. R. Rahayu and Satria, "Metode Certainty Factor dalam Mendiagnosa Gangguan Perkembangan Anak," Jurnal Gerbang, vol. 8, no. 2, 2018.

[6] A. Arifin, S. Hanif and S. Kusumadewi, "Model Pendukung Keputusan Kelompok Untuk Penentuan Faktor Dominan Keharmonisan Rumah Tangga," in Seminar Nasional Aplikasi Teknologi Informasi (SNATi), Yogyakarta, 2018.

[7] Hardianto and D. I. G. HTS, "Penerapan Metode Fuzzy Multi Criteria Decision Making Menentukan Pemilihan Laptop," IT Journal, vol. 6, no. 2, pp. 207-216, 2018.

[8] J. Nasir and Jahro, "Sistem Pakar Konseling Dan Psikoterapi Masalah Kepribadian Dramatik Menggunakan Forward Chaining Berbasis Web," RABIT : Jurnal Teknologi dan Sistem Informasi Univrab, vol. 3, no. 1, pp. 35-46, 2018.

[9] W. Morris and Firebaugh, Artificial Intelligence: A Knowledge Based Approach, PWS, 1989

[10] S. Kusumadewi, S. Hartati, R. Wardoyo and A. Harjoko, "Penggunaan Operator Quantifier Guided Dominance Degree (QGDD) Sebagai Certainty Factor pada Clinical Group Decision Support System (CGDSS)," Seminar Nasional Aplikasi Teknologi Informasi (SNATI), pp. 21-24, 2006.
[11] E. J. G. Harianja, "Penentuan Penerima Beasiswa Dengan Forma Preferensi Menggunakan Metode Simple Additive Weighting (SAW)," METHODIKA, vol. 2, no. 2, pp. 189-192, 2016

[12] B. Gregorius S, I. Irawan and J. S. Natalia, "Fuzzy Preference Relation untuk Membantu Pengambilan Keputusan Multi-Criteria Pemilihan Supplier," in KonferensI Nasional Sistem dan Informatika, Bali, 2008

[13] K. Sri and H. Wahyuningsih, "Model Sistem Pendukung Keputusan Kelompok Untuk Penilaian Gangguan Depresi, Kecemasan dan Stress Berdasarkan Dass-42," Jurnal Teknologi Informasi dan Ilmu Komputer (JTIIK), vol. 7, no. 2, pp. 219-228, 2020.

[14] S. Kusumadewi and S. Hartati, "Basis Pengetahuan Dengan Model Keputusan Kelompok Untuk Diagnosis Gangguan Kejiwaan," BMIPA, vol. 1, pp. 28-42, 2008.

[15] R. R. Rahayu and Satria, "Penerapan Metode Certainty Factor Dalam Mendiagnosa Gangguan Perkembangan Anak," JURNAL GERBANG, vol. 8, no. 2, 2018.

[16] F. Chiclana, "Some Induced Ordered Weighted Averaging Operators and Their Use for Solving Group Decision Making Problems Based on Fuzzy Preference Relations," European Journal of Operational Research, vol. 1, p. 182, 2007.

[17] H. Sumasno, "Pemeriksaan Keabsahan Data Penelitian Kulaitatif Pada Skripsi," Jurnal Ilmu Pendidikan, vol. 22, no. 1, pp. 74-79, 2016 